\title{
Project-based civics education: A case study of a university research center
}

Talip ÖZTÜRK*
Social Studies Education, Ordu University, Ordu, Turkey
ORCID: O000-0003-3543-0468

\section{Introduction}

Progressive and reconstructive education philosophies have brought the project-based learning approach to education systems as a practice in line with the increasing importance of thinking skills in all countries' education systems. Project-based learning is accompanied by critical thinking as a method to raise individuals who are sensitive to world problems. Therefore, individuals are responsible citizens in their community combine project-based learning with critical thinking and stay at the center of project-based civics education.

Project-based learning is a model that organizes learning around projects made by students in the education field. Projects are complex tasks based on intriguing questions or situations in design, problem-solving, decision-making or to engage in task-based activities and to let students work relatively autonomously over some periods and to result inapplicable and suitable

\footnotetext{
*Correspondency: talipozturk@odu.edu.tr
} 
products or presentations (Ngeow \& Kong, 2001; Thomas et al., 1999). Initially, project-based learning has been accepted as an approach rather than a particular method or process. Therefore, there seems to be a lack of an agreement regarding a standard definition to identify it. This approach is learning from a working process to understand or solve a problem. Project-based learning is a collection of information about the problem in which students learn to analyze the information manually and synthesize it to come up with some solutions to solve the situation. Boud and Feletti (2003) state that the initiating point of learning is a problem. Still, projectbased learning is one of the most effective teaching and learning methods to encourage students to engage in their schools.

From this perspective, project-based learning can be seen as a complete problem-based learning task through which students can find ways to detect or solve a real-life problem. Therefore, students can collaborate with other students, using their critical thinking, creative thinking, managing time, and other skills and the appropriate attitudes and skills they need to use. These experimental learning opportunities allow students to develop their learning and critical thinking skills (Sonmez \& Lee, 2003).

One of the early supporters of the project approach at the beginning of the $20^{\text {th }}$ century was Dewey (Evenson \& Hmelo, 2000), an educational theorist who presented a 'problem state' and had students about real-life situations and provided resources to state problems. The project approach was very new in those years, and until the end of the 1960s', this approach did not receive any interest from researchers and educators.

\section{Civic Education and Project Citizen}

As people started to live together and formed the social institutions they needed and started organizing social life by organizing these institutions, they needed individuals who would adapt to social life and the rules created. In this system, the concept of state, citizen, and citizenship has emerged (Akbaş, 2008). The citizen is the person who accepts the sovereignty and legal rules of the state to which he is affiliated and has obligations against these rules (Kan, 2009). Civic education aims to prepare individuals for future adult life's roles and responsibilities by raising citizens aware of their rights and responsibilities (Y1lmaz, 2013). In other words, civic education contributes to ensuring justice and equality in society.

While it is evident that citizenship education is so essential for future citizens, it is increasingly significant to use methods based on students' active participation instead of traditional teaching methods. In a study conducted by Ersoy (2016), although there are studies about citizenship education, they are not at desired levels. With the decreasing rates of civic engagement, especially in some countries, it has become evident that citizenship education centers are needed more. However, the question here is; how can terms of "project" and "civic education" come together? One of the best answers to this question probably is Project Citizen.

Project Citizen program started in California in 1992 and expanded to a national program in 1995 across the US. It is a subject-oriented instructional treatment to improve the knowledge, skills, and tendencies of democratic citizenship in government and civil society participation. The program forces students to take an active interest in government and non-governmental organizations to address a school or community issue and achieve the social and intellectual capital necessary for responsible democratic citizenship. So, the Project Citizen's objective is to motivate and empower students to use the rights and responsibilities of democratic citizenship by intensively examining a public policy issue in their schools or communities. The teaching materials are designed to help students learn and monitor public policies, develop the 
skills necessary for responsible and effective citizenship, and learn to use their rights and responsibilities. This program allows students to participate in government and civil society while conducting social action for critical thinking, dialogue, discussion, negotiation, cooperation, modesty, tolerance, decision-making, and public interest (Center for Civic Education, 1998, 1-11). The expected outcomes of Project Citizen are to increase the quality of intelligent, innovative, participatory, respective, and responsible citizens (Adha et al., 2019; Trisiana, 2015).

Within the scope of Project Citizen activities, a six-step process would allow students to define and study one major issue. These steps are as follows: identifying problems, selecting a problem, researching the problem, develop a portfolio to present research, presenting a portfolio in a simulated public hearing, and reflection (Center for Civic Education, 2020b). Preparing a Project Citizen portfolio takes around one trimester or semester, but it will mostly depend on the instructor's syllabus. It is not compulsory for all levels, including secondary, high schools, and university levels; the school community, teachers, students, school management, and the university professors decide whether it be in-curricular or extra-curricular activity.

Center for Civic Education (2020a) states that Project Citizen teachers and students are encouraged to participate in competitive local, regional, state, or simulated national hearings in the US and 75 other countries worldwide. Although there is no obligation to participate in the program, competitions motivate the student's learning, reward the student's success, and highlight the program to community members and potential financial institutions.

Some previous studies have examined Project Citizen as to student attitudes (Fry \& Bentehar, 2013), application processes and reflections in varying countries (Liou, 2004), or inform teacher practice through the evaluation (Morgan, 2016). However, Project Citizen's application through a research center lacks in the literature and whence is worth researching.

The need for reform in university systems and the need to put together scholars from diverse perspectives to address complicated problems of various kinds led to the establishment of university research centers (Berbegal-Mirabent et al., 2015). According to the Research Centers and Services Directory, there are over 15.000 university-based research centers in the United States and Canada (Miskelly, 2011) and over 38,000 globally (Bishop, 2012). Due to the centers' heterogeneity and their wide variety of goals, the literature lacks a consistent description of university research centers and defines them (Sabharwal \& Hu, 2013). A research center is " $a$ higher education institution in which education and training, application and research are carried out for the application needs of various fields and preparation and support activities of some professions to support education and training at universities (CoHE, 2020)." Research centers are developing a new paradigm for who conducts testing and the research's impacts and aims. They will significantly improve a university's capacity to receive external funds, provide opportunities for interdisciplinary cooperation among faculty, and give the research university significant recognition and reputation in a specific field of study (Tash, 2006). The desire to encourage cooperation between researchers is a shared feature of all university research centers (Boardman \& Corleyb, 2008; Franco \& Pinho, 2019), and universities must help develop centers in terms of mission, funding, and space (Fink, 2004).

Previous studies often have not made significant progress in understanding university research centers' contributions to Project Citizen. Research centers at universities mostly seem to induce outputs and behaviors that have not been encouraged in the traditional context of the academic department (Boardman \& Corley, 2008). 
By focusing on a university research center case, this study contributes to the broader literature that compares different structures for coordinating researchers and research projects. By examining the activities of research centers in higher education institutions, in-depth studies can be conducted by interviewing the directors and staff of the centers; thus, it helps to obtain more functional findings on the effectiveness of these centers (Öksüz Gül \& Alpaydın, 2017).

Based on the literature review, in this study, examining educators' opinions is done in a research center established in a state university in the Mid-Western United States and having an interdisciplinary study on project-based civics education. It is expected that the studies carried out at this center and the researchers working in this center on the project-based civics education will serve as an example for the examinations of social studies education in the countries where project citizen is implemented.

Due to that implementations of Project Citizen go back to 1992, studies on this subject may seem outdated (Öztürk et al., 2021). However, the lack of a single study related to research centers and the fact that project citizen is not-yet-known in many countries reveals the importance of this study. The study's basic assumption is that participants' opinions should be known towards project-based citizenship education to explain how a research center can be formed as an exemplary institution in support of Project Citizen. In this context, the central question of this research is: "How does citizenship education take place through project-based learning via a research center at a university in the US?" The following sub-questions are answered in the research:

(1) What is the role of the university-based research center in citizenship education through project-based learning?

(2) How are the participants' opinions at the research center for project-based civics education in terms of teacher training and student guiding?

(3) What would the participants' opinions be like if this research center were to be transferred to other countries/institutions?

\section{Methodology}

A case study, which is one of the qualitative research methods, is used in this research. The study adopted the holistic single case pattern. The university and research center selected for the study exemplify cases of original projects and inferences deemed informative about the organization's experiences (Yin, 2014). Besides, the case study research helps expand experiences for practitioners and policymakers (Stake, 2005).

\section{Researcher's Role}

The researcher completed his Ph.D. in Social Studies Education and worked on projectbased learning. The researcher held a visiting scholar status at the university and research center during the 2018-2019 academic year. He studied theoretical and practical aspects of projectbased learning and had the opportunity to examine various sources related to project-based civic education. These resources included information about the projects carried out by the faculty members at the center, articles published in journals, books, and other available sources such as Project Citizen portfolios from previous showcases. The university's name and the research center where the research data is gathered, and participants' personal information is kept confidential for ethical considerations. 


\section{Participants}

The study group comprises some faculty members and administrators working in the faculty of education and citizenship center and teaching assistants who had Project Citizen's experience. The participant numbers, positions, work/study fields, and genders of the participants are shown in table 1.

Table 1: Participants features of the research

\begin{tabular}{llll}
\hline Participants & Position & Field & Gender \\
\hline Participant 1 & Faculty Member & Social Studies Education & Male \\
\hline Participant 2 & Faculty Member & Social Studies Education & Male \\
\hline Participant 3 & Faculty Member & Social Studies Education & Female \\
\hline Participant 4 & $\begin{array}{l}\text { Faculty Member and Research Center } \\
\text { Administrator }\end{array}$ & Social Studies Education & \multirow{2}{*}{ Male } \\
\hline Participant 5 & $\begin{array}{l}\text { Faculty Member and Research Center } \\
\text { Administrator }\end{array}$ & Social Studies Education & \multirow{2}{*}{ Female } \\
\hline Participant 6 & Teaching Assistant & Curriculum and Instruction & Female \\
\hline Participant 7 & Teaching Assistant & Social Studies Education & Female \\
\hline Participant 8 & Teaching Assistant & Social Studies Education & Male \\
\hline Participant 9 & Teaching Assistant & Social Studies Education & Male \\
\hline Participant 10 & Teaching Assistant & Social Studies Education & Male \\
\hline Participant 11 & Teaching Assistant & Social Studies Education & Female \\
\hline Participant 12 & Teacher & Social Studies Education & Male \\
\hline
\end{tabular}

Twelve people agreed to participate in this study, and a great majority of the participants were from the field of social studies education. All participants apply Project Citizens as in-curricular activities in their courses at the university where they work and have previous experience on the subject. Due to their administrative duties in the center, Participant 4 and Participant 5 mostly provided data on the research center's structure and characteristics. There is also a teacher in the list of participants (P12). In selecting this participant, it is taken into consideration that he/she has participated in an in-service training about the project citizen given by the research center.

Qualitative research, by nature, does not aim to generalize findings to the universe. However, there are some sampling methods for qualitative research methods. The criterion sampling method was used to determine the research participants planned to be held at the university. In criterion sampling, individuals, groups, or settings have selected that meet any criteria that researchers put forward. This sampling technique is typically utilized for quality assurance in research (Miles \& Huberman, 1994) and results from a specific criterion of selection by the researcher. The researcher decides which type of individuals or situations to work for and determines the criterion. The criterion determined in this study was having teaching experience/publication in project-based learning and/or citizenship education. The staff list and the resumes of the personnel have been reached from the university website.

\section{Data Collection and Analysis}

The research data were collected using two methods: interview and observation. The data obtained from the interviews were compared through observation and to present a more reliable and valid structure for the findings. An interview is considered the primary data collection method.

Within the frame of publication ethics and other relevant ethical considerations, some measurements were taken by the researcher. The researcher compiled the application for ethical 
permission, and the preparation of the necessary documents and Institutional Review Board (IRB) approval was received by the faculty member who hosted the researcher. The researcher had to pass the "Collaborative Institutional Training Initiative (CITI)" test to obtain IRB approval. The IRB board requires this test of the relevant university from all applicants. After the approval of the IRB, data collection studies were initiated.

Interview: The data were collected through the semi-structured interview form that the researcher prepared. The draft form was initially composed of 8 items prepared by examining the related literature. The opinions of two faculty members who were experts in social studies education were consulted to check the questions' extent and comprehensiveness. The form was finalized in line with the experts' suggestions that some items may cause repetition, add questions at the end, and make statements clear and understandable. The final form consists of 5 open-ended questions and probe questions. The interviews were held in the first weeks of the 2019 spring semester with the planned schedule participants.

The researcher prepared an interview contact list and contacted them by e-mail. Interviews were done with people who agreed and volunteered to participate by replying to the invitation e-mail. In total, twelve interviews were conducted individually with the people on the interview list.

Table 2. Interview schedule

\begin{tabular}{llll}
\hline Participant Code & Interview Site & Date / Time & Duration \\
\hline P1 & Faculty Office & $11.01 .2019 / 10: 00$ & $25^{\prime}$ \\
\hline P2 & Faculty Office & $15.01 .2019 / 11: 00$ & $34^{\prime}$ \\
\hline P3 & Faculty Office & $18.01 .2019 / 09: 30$ & $21^{\prime}$ \\
\hline P4 & Research Center's Library & $21.01 .2019 / 14: 30$ & $19^{\prime}$ \\
\hline P5 & Research Center's Library & $24.01 .2019 / 11: 15$ & $20^{\prime}$ \\
\hline P6 & Faculty Office & $31.01 .2019 / 08: 30$ & $27^{\prime}$ \\
\hline P7 & Meeting Room & $31.01 .2019 / 15: 00$ & $28^{\prime}$ \\
\hline P8 & Meeting Room & $05.02 .2019 / 14: 45$ & $30^{\prime}$ \\
\hline P9 & Meeting Room & $06.02 .2019 / 11: 00$ & $24^{\prime}$ \\
\hline P10 & Meeting Room & $20.02 .2019 / 12: 00$ & $28^{\prime}$ \\
\hline P11 & Meeting Room & $21.02 .2019 / 15: 30$ & $24^{\prime}$ \\
\hline P12 & School's Meeting Room & $07.02 .2019 / 13: 00$ & $25^{\prime}$ \\
\hline
\end{tabular}

As presented in Table 2, 4 of the interviews were held in the faculty office, 2 in the research center library, and 5 in the department meeting room, and each interview lasted approximately 25-30 minutes.

The transcription of the data set is done by using Dragon Professional software. The researcher checked all data sets after transcription, and software errors were corrected manually, then the transcriptions were e-mailed to the participants to receive their confirmation.

The content analysis process is followed as; data coding, finding themes, organizing codes and themes, and defining and interpreting the findings. The resulting codes were gathered and examined, and themes and sub-themes that could collect the codes under specific categories were found. The results are presented as in descriptive narration and supported by direct quotations. While the findings were reported, participants were coded as P1, P2, .. P11.

In the first stage of qualitative data analysis, it is necessary to determine the themes that can explain the data set in a more detailed manner and collect the codes under specific categories based on the discovered codes. Thematic coding identifies the similarities and differences of codes with different features and groups the codes related to each other in this mediation 
(Baltac1, 2019).

Observation: Participatory observation method was used as a data collection tool, and interview data were supported. In this way, the accuracy and validity of the interview data obtained were ensured. The researcher recorded his observations by taking notes in the observation notebook. These records were examined during the interview questions and points that support/do not support the interview topics were included in the study.

Applications made to ensure internal validity in this research are triangulation, long-term observation, peer examination, member checks, stating researcher's biases, and participatory modes of research (Merriam, 2001). In case studies, it is stated that trustworthiness should be provided by validity and reliability (Bassey, 2000). The researcher used different data sources and made long-term observations to ensure reliability. The observation period is a semester during which the course takes place. The data were checked and approved by the data sources, a different person checked the research findings than the researcher, and the research report was tried to be prepared in detail.

\section{Findings}

Three themes forming the findings of the research are in figure 1.

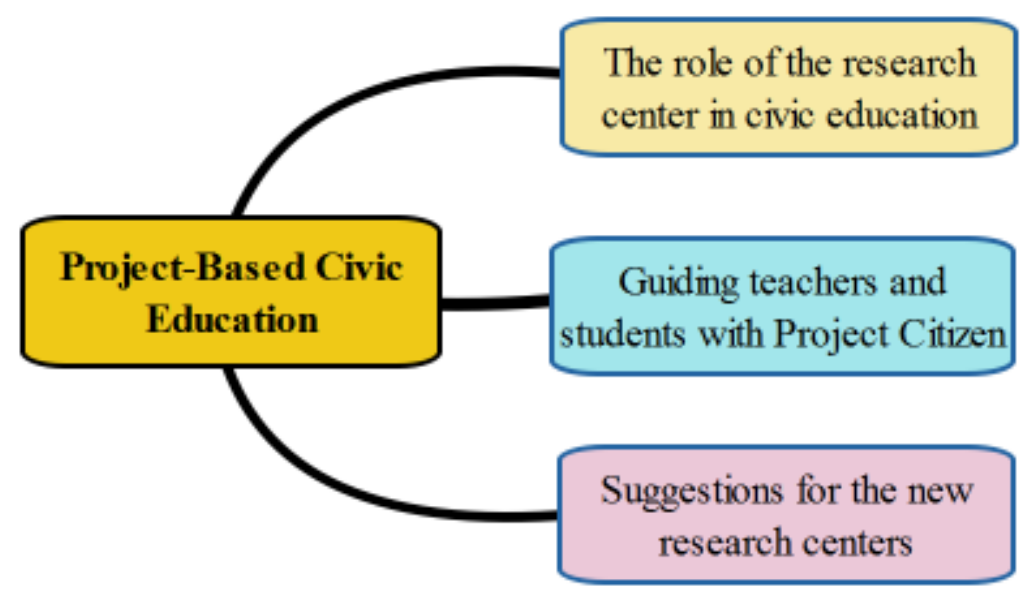

Figure 1: Themes of the research findings

\section{Theme one: The role of the research center in civic education}

The concept of citizenship expresses unity by nature and focuses on the unity of society. In this sense, the education of the society needs an organized structure. From this perspective, it is crucial to present the university's citizenship research center where the research is carried out and the priority given to citizenship projects as the first theme. Participants' opinions on the democratic citizenship center subject to the research are analyzed and presented here.

When the participants' opinions regarding the role of the research center in citizenship education are analyzed, it is seen that the existence of the citizenship center has an active role in citizenship education. Participants indicated that research centers should be considered for implementing the Project Citizen. From the participants' opinions, the research centers' roles of education are in four categories: these are Features and works (1), aims and missions (2), facilities (3), and budget (4). 


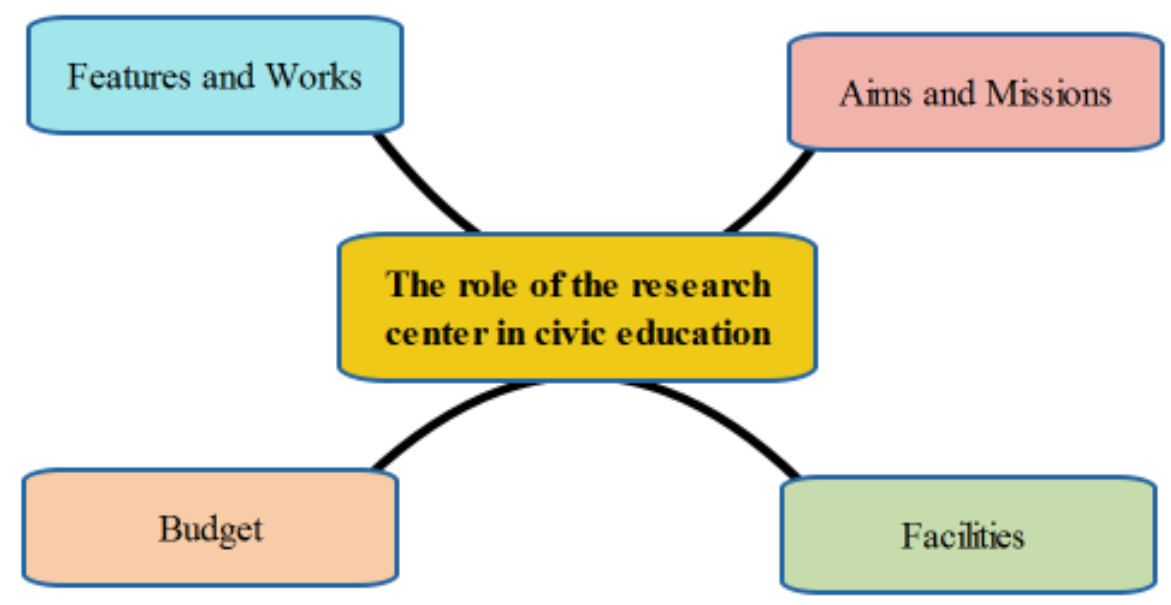

Figure 2: Categories of the Theme 1

Features and Works (1): This first category presents the findings of the research center's characteristics and studies, thus covering the identification of the center's works. Interviewees (P1, P3, P4) acknowledged that research centers are essential for project-based civic education. The researcher's observation reports also show that the center's features, such as the number of staff, space, library, and alike are present for supporting project-based civic education. Here are some quotations from the field notes:

\begin{abstract}
"The research center is located on one of the floors of the education building. When you enter the center, you will first be greeted by a library and a section with books. It is noteworthy that the books are generally focused on citizenship education. Next to the library is the research center information desk, and opposite it is the director's room. On the walls, examples of posters from the activities of the research center draw attention. The library of the research center is open to general researchers. Besides Project Citizen, the center organizes constitution day celebration, educator workshops, and professional development for teachers."
\end{abstract}

The researcher's field notes provide data on some characteristics of the research center. When the center's web page is examined, it is connected within the College of Education hierarchically. However, studies criticize the state of the centers depending on the rectorate (Öksüz-Gül \& Apaydın, 2017). In the center examined here and the project citizen, it is seen that works have been implemented such as constitution day, holocaust remembrance conference series, professional development for teachers, and citizenship class open to the public according to its website. In addition to qualitative studies that specifically mention the works conducted by research centers in the literature (Güleç-Aslan, 2018), studies are present in which the center's number of work outcomes, number of staff, number of training, and logos are also examined.

Aims and Missions (2): The center's "mission is to assume a leadership role in preparing the next generation," says the web page. In the second category of the first theme, this center's aims and missions are examined, and participants' views on this category are presented below:

"We run professional development workshops for teachers, but we also do with the focus on civic education for K-12 students, and primarily that is our Project Citizen program" (P4) 
As stated by P4 in the showcases, the teachers' professional development, the researcher observed in a showcase as a timekeeper, was supported in the center by workshops and other professional ways.

“... So this center for democratic citizenship as an engagement center is here in the College of Education. Our mission is to take the message of civic and economic education to K-12 teachers and K-12 students, and we have a wide range of programs that we run like a showcase for Project Citizen" (P2)

The high level of participation and interest in the showcases organized by the center shows that it is carried out from a broad perspective. As noted in the observation notes, teachers and students carry out these projects throughout the year and present them in front of the jury.

"... So yes, this center coordinates those showcases, we find the venue to recruit the judges and timekeepers, we coordinate the scoring and sharing that information with the teachers. Then we get feedback from the teachers on how things went and how we can improve things." (P3)

According to the researcher's field notes, as supported by P3, the teachers score and make some constructive suggestions about students' projects in showcases. As stated in the Project Citizen features, the center's active role in organizing Project Citizen showcases is a developmental feature.

Facilities (3): Regarding the research center's facilities, it is understood from the field notes and following the participant's opinion that it has a good library that helps carry out essential studies on civics and Project Citizen. It serves not only university students but also other community members. Besides the university's central library, this section, where resources can be found on some remarkable subjects, is designed for many researchers to come and study.

“... we have a very good library, people can use this library, probably the administration will tell you more about the history of the center and how it came to be. Nevertheless, we support many professional development activities with teachers, and teachers get the run at least every other year; we run summer institute for teachers. We prepare many programs here on campus that address the number of questions of civic education not only for students but for everyone from the general population." (P5)

Based on observation reports, the citizenship center serves in a structure that takes care to carry out its activities to produce, guide and organize projects in a way that covers the entire target audience. As indicated by P5, local showcases organized on campus and state-based showcases can be shown as evidence.

Budget (4): As the fourth category of this theme, the budgets of research centers are among the most critical issues determining their studies' width. One of the participants explains how the research center can work financially independently:

"This center is an endowed center. By that, I mean 30 years ago, a successful businessman gave the college a very large donation, and each year the interest from that donation is used to run our center activities. That is what the endowment is, so it is called a spin-off, and the endowment spins off a small percentage of the funds, and we use those each year to do our programming, so all of our programming, constitution day, our professional development series that are lecture series, to the Project Citizen work and all of those activities are funded out of the endowment. So we do not need to fundraise, which is nice. Our programs cost about as much as the money we have to spend." (P4) 
Endowment money is often used for assistance to develop centers, but it is scarce and difficult to come by (Hall, 2011). For this center, as stated on the website, a gentleman and active business community member gave a generous gift to the School of Education at the university to endow the center in 1994. According to P4, the fact that they do have financial support lessens financial concerns, so it has great importance in a business's success. As the researcher field notes support, this will help in many ways, such as preparing the materials used for the education and the execution of teacher training and the organizations held on essential days (independence day, and so on.).

\section{Theme two: Guiding Teachers and Students with Project Citizen}

In-service training activities organized to develop teachers' knowledge and inform them about the current developments will positively affect teachers' personal and professional development. In addition to organizing showcases for Project Citizen, the participants state that the research center contributes to disseminating the project by conducting teacher training and student guiding. P1 stated the following regarding teacher training:

"We just sat together and watch the videos and talk through things, and then we meet with them again through the semester once or twice. Depending on what they want and just answer questions and talk to them about where they are. We also offer to come in and teach small lessons, like if there is a particular part that they are concerned about teaching, interviewing skills or teaching, you know, how to define a public policy issue.” (P1)

In the interview with $\mathrm{P} 4$, it was stated that one of the most challenging stages of Project Citizen regarding students and teachers in public policy. It is thought that in-service training activities help teachers and students in such matters make an essential contribution.

"We will go in and teach that for them. The teachers recently have assets to do it. We used to have and what we should do more of that with some other teachers. These teachers, though, have asked us to come in and talk with students directly." (P3)

Project Citizen can be a complicated process to understand and implement at first for unfamiliar people. For this reason, it seems that the center's guidance is an important feature. P4 stated the following regarding student guiding:

"So what we have done for all of them is to go in and sit down with each group of kids and
help in their research, or the middle of the research, just ask them questions about "who did
you talk to?" "what are you thinking about?" "have you thought of that?", and we try to
sort of preview the questions that they will be asked in the showcase that they are ready for
that. When we do that, the teachers find that the kids take it more seriously than when their
teacher does it. It is an outsider coming in, you know, they want to impress us a little bit.
... After we come and talk to them and then like you are going to talk to judges and
legislators about this". (P4)

The views of faculty members $(\mathrm{P} 2, \mathrm{P} 7, \mathrm{P} 9)$ that this center has expanded the practice of projectbased citizenship teaching are as follows:

"Because you have participated as a problem-based approach to understand public policy how it has developed and how it influences how citizens can help influence, developing it, and how public policy impacts on students so that students who are in middle school or high school identify an issue public policy question that they are curious about, they interview stakeholders that collect data that surveys that might read newspapers and do online searches. They develop an action plan, and they develop a portfolio that supports 
whatever action plan relative to that public policy issue, and then they present that to a showcase." (P2)

"It is a simulated City Council or County Council. There are usually three or four judges. For example, to get a stop sign put in front of the intersection on the corner near school, you go to the city council and say, "Here is the reason I want that stop sign there. People are speeding their accidents that are happening. The police chief said they give more tickets at that intersection than any other place in the city, etc." I knew I would have to convince them to make a change in the public policy, in this case, the law to implement that stop sign. Students do that." (P7)

"In the showcase, panel judges have a rubric that they provide feedback. They score or grade of the presentation as well as the data that they have to support their public policy choice and then their argument, and then they give them feedback." (P9)

In light of these findings, it is evident that the center provides crucial information to teachers and students. In the interview with one of the teachers who received the Project Citizen training, he expressed the following about the education they received on this subject:

"... Me and another teacher had instruction from the university. A woman and another gentleman came for three or four times. They give a seminar and show examples. They did have some kind of training, and they were helpful. They were definitely helpful, but still, they want to see you actually do it and then see how it is going." (P12)

The research center helps K-12 educators implement a high-quality curriculum in the classroom in social studies, civics, or economics. As a week-long intensive workshop on a particular subject, the center offers different professional development formats, including an evening series during the school year and a summer institute. From these points of view, it is considered an important finding that a research center also functions as an in-service training center. It is also seen that the dissemination of the Project Citizen's application and the guideline studies for practitioners are works that serve its essential functions.

\section{Theme Three: Suggestions for the new research centers}

In line with the third aim of the research is to get suggestions for establishing a similar research center in line with the participants' opinions to implement and disseminate effective citizenship education on a project-based basis. The participants' opinions on the third subproblem might be regarded as essential in the sense of their future vision for other countries. The reason for including the expressions of P4 and P5 is because that they have considerable experience as they have administration positions. Interview with the research center's director has given recommendations for the establishment of such a center are as follows:

"I think the most difficult things are increasing awareness of critical decision-making in thinking, you know, democratizing and getting people involved in their civic engagement and so on. So, assuming there is demand for that, I think our model is rare. We had one benefactor who was extremely generous and had left the legacy; however, if you can find an individual who is committed and has the resources, probably not a politician. I mean somebody who is us express a successful businessperson, maybe even someone who has been university faculty member but has the resources available to them down on a run just Project Citizen. Take fewer resources than to run our whole center, thinking about "what would it cost." (P4)

The ability to establish a research center in a university may not be very demanding, provided that specific procedures are followed. The point stated by the $\mathrm{P} 4$ here is actually 
on how effective the activities of the research center can be carried out. P4 also associated this with the state of society's readiness for the democratization process. The name of the research center was given to the center due to the businessman's donation, as it was mentioned in the first theme. P4 emphasizes that it would be the right approach for the center's director to become an entrepreneur.

P4's views on the dissemination of the project citizen also come to its availability in other languages. P4 explains this situation as follows:

"I am not sure; I probably should have looked it up, but the Project Citizen has been translated into something like 15 languages. I do not know if Turkish is one of those or not. So if it is already translated in the form that you can use it, that is simply a matter of making agreements with the Center for Civic education to utilize that they probably would ask for some small fee because you have to print them yourself. You can get the workshop manual for running training online there, but there is a PDF of it; this is how you set up a workshop to train teachers." (P4)

Center for Civic Education provides material support to entrepreneurs who request it. However, there may be limitations as to the applicability of the materials in every country. The center conducts and funds workshops on Project Citizen for students and teachers. It also holds the Project Citizen public showcase and award ceremony twice a year. Local officials, lawyers, judges, faculty, and media members are among the judges for this Project Citizen showcase. P5 explains the responsibilities of the research center with the showcases and gives information about their duties.

"This is how you run a showcase, and so you will not need many resources you need access to a place to hold that you'll need to provide food and refreshments for people. You'll need to know cases and give a gift to judges thanking them for their time so you can run a showcase with your hundreds of students for a relatively small budget." (P5)

P5's views are essential in terms of revealing what they experienced in showcases. To organize a showcase can be said that it is appropriate to provide jury members who are dedicated and volunteers, who value the work of the students, and invite an audience open to learning. Accordingly, it is worth considering his views by policymakers and scientists.

\section{Discussion, Results and Suggestions}

Project-based civic education prepares active citizens who know how to analyze and solve a problem using scientific research steps. Project Citizen is an effective citizenship education that could be a viable option for a country's citizenship education course. Studies show that Project Citizen has a positive impact on civic literacy and efficacy (Atherton, 2000; Liou, 2004; Root \& Northup, 2007; Tolo, 1998; Vontz \& Nixon, 1999; Vontz \& Patrick, 2000). Besides, Project Citizen is a model that develops knowledge, skills, and attitudes that students develop their cognitive, affective, and psychomotor skills (Budimansyah, 2009; Sulistyarini et al., 2019).

Research centers appear in many ways as unique institutions. It is a fact that the priority of university research centers is to host scientific research activities (Ertan, Yol \& Savaş, 2019). These centers have more interdisciplinary culture than the faculties because it brings together researchers from different specialties. They create a bridge between the university and the local community (Steffensen et al., 2000). 
This study was carried out to examine the practitioner's views and researcher's observation on Project Citizen's application in an American university research center. The results are given below in the order of the sub-problems.

In the first sub-problem study examining the role of the citizenship education center, it is concluded that the research center had essential contributions. It is seen that among the ways to make this contribution, there are administrative, budget, and personnel factors.

The success of a research center depends mainly on its excellent financial well-being (Kumar, 2017). However, financial difficulties are among the most significant and common problems of research and application centers (Öksüz Gül \& Alpaydın 2017). Since the centers are not units that receive grants financially from universities, it has been stated that they should find sponsors and support for research and implementation activities (Steffensen et al., 2000).

Research points out that researchers tend to open research centers to receive support and funding in the USA. Among the reasons for this are support from the labor market, work intertwined with industry, and faculties have the opportunity to carry out research (Mallon, 2006). It is noted in another research that a significant deficiency is to be financed by the private sector in research and application centers in Turkey (Öksüz Gül \& Alpaydın 2017).

Since the research centers do not have their own budget, they do not have expert staff either. It is a fact that most of the research centers complain about financial difficulties. The centers should be encouraged to collaborate with prominent international organizations. This support will pave the way for research centers to have human and financial resources within themselves (Savaş et al., 2018).

Research centers typically receive financial support from one of these three sources: endowments, college grants, or self-financing advisory projects (Kumar, 2017). Firstly, the center will seek an endowment during the funding period, and the endowment will then support the center. The endowment is ideal for any research center, as the financial requirements are usually taken care of. Second, the university may provide funding for the center. This type of grant reflects the university's commitment to fostering a research-oriented learning environment, and it is a valuable option for the university to attract promising talent. Finally, the center can be self-funded by raising funds through consulting ventures to compensate for its life and straightforward service.

The findings of this research also reveal the center's personnel and their qualifications have also influenced. Influential center directors and counsel center executives to follow these tested strategies: focus on the center's mission by going beyond conventional faculty positions to fill a gap with clients in an applied field; have a broad vision for the center's potential and express it passionately to create partnerships with federal and other funders, ensure that technology is part of the center's product and process management combination. Implementing these unique techniques into regular center activities will improve the center's chances of success (Hall, 2011). Hiring a high-quality, self-managing core team, including graduate and postdoctoral students, is also critical to center staff management (McCarthy et al., 2000).

In line with the second sub-problem of the study, it is seen that the research center made significant contributions to student education and teacher guidance. This result is essential in revealing the contributions of a research center towards the development of social studies education. 
Research centers can be regarded essential for project-based civics education that can be carried out at universities, and they make significant contributions in the dissemination of the Project Citizen application. In sum, the research center plays an active role in addressing this practice's problems by providing the teachers with the necessary in-service training support.

Having conference meetings and conducting the applied study are direct resources that improve academic reputation while promoting scholarly practices (Matkin, 2001) in research centers. However, in the dissemination and implementation phase of the Project Citizen, it should be accepted that university research centers have significant contributions, based on the USA's example.

In line with the third sub-problem of the study, this study's findings guide how it should be in the direction of the university-based research centers and educators can serve as sources of breeding programs in other countries. Although the establishment of research centers requires different bureaucratic procedures and processes for countries. One of the most important reasons for the centers' existence is that they create studies that increase the applicability of innovative approaches. According to this research findings, the fact that most of the research centers complain about financial difficulties is a reality in Turkey; however, given the fact that universities do not have a separate budget for research centers, it is crucial to provide an expansion towards foreign resources (Savaş et al., 2018). Güleç-Aslan (2018) emphasizes the significance of studies that examine university-based centers. From this perspective, the research center case examined in this study reveals good recommendations concerning disseminating research centers.

The vast majority of the centers only organize conferences, seminars, and social-cultural events to raise awareness. In contrast, a small portion of the centers undertakes other educational activities and academic and non-academic projects (Savaş et al., 2018). At this point, various studies should be carried out in order for these centers to be more active. Various incentives and supports should be provided by universities and other relevant organizations (Ertan et al., 2019).

Consequently, this study provides information on how the project-based civics education process should be conducted through a university-based research center. Based on the findings, in such a process, qualified professionals with professional competencies, counseling process, expert training, and collaborative work are particularly outstanding issues.

Project Citizen is an approach that emerged in the US; however, not all universities in the country have centers that implement Project Citizen in their higher education. Due to this case study's nature, it may also be the case that representative and applicable activities in education and research are introduced through in-depth analysis and constitute an exemplary practice.

There are various limitations of this study. It is limited only to the center where the study visit occurred and to a certain number of participants and observations. Besides, quantitative data were not collected in the study. It is sure that building future studies by considering such issues will help improve them.

In line with the findings of the study, the recommendations regarding the field of application are as follows:

- The research centers' role in the application process of Project Citizen might be strengthened across the countries based on the findings of this case.

- If it is planned to start implementing the Project Citizen in other institutions, it will help establish a university research center that will carry out this practice. 
- It may be suggested to make the necessary changes in the directives and regulations to make the research and application centers in universities more active and take the example of the research center carrying out the Project Citizen application within the scope of this research.

- It is recommended to use the research center's advantages examined in this study in terms of financial and economic management as an example. Centers should have their own budget allocated for meetings, panels, and other activities.

As for future directions for research concentrating upon the same area, similar research centers' civic education activities can be examined to obtain a broader academic perspective. Research on different centers and participants, with dissimilar research models and methods, and crosscultural comparative research can be carried out.

\section{Acknowledgments}

The author gratefully acknowledges the support of The Scientific and Technological Research Council of Turkey (TUBITAK) for this research.

\section{References}

Adha, M. M., Yanzi, H. \& Nurmalisa, Y. (2019). Open classroom climate: Project Citizen model in civic education learning activity. Pedagogia Jurnal Ilmu Pendidikan, 17 (01), 13-22.

Akbaş, O. (2008). An overview of trends in values education. Journal of Values Education, 16 (6), 9-27.

Atherton, H. M. (2000). We the People: Project Citizen. In S. Mann \& J. Patrick (Eds.), Education for civic engagement in democracy: Service learning and other promising practices (pp. 93-101). Bloomington, IN: ERIC Clearinghouse for Social Science Education.

Baltac1, A. (2019). The qualitative research process: How to conduct a qualitative research? Ahi Evran University Institute of Social Sciences Journal, 5(2), 368-388.

Bassey, M. (2000). Case study research in educational settings. Philadelphia, PA: Open University Press.

Berbegal-Mirabent, J., Sánchez García, J. L. \& Ribeiro-Soriano, D. E. (2015). Universityindustry partnerships for the provision of R\&D services. Journal of Business Research, 68 (7), 1407-1413. http://dx.doi.org/10.1016/j.jbusres.2015.01.023

Bishop, P. R. (2012). Impacts of an interdisciplinary research center on participant publication and collaboration activities. (Unpublished PhD dissertation). University of Tennessee. TN. https://trace.tennessee.edu/utk_graddiss/1511

Boardman, P.C. \& Corley, E. A. (2008). University research centers and the composition of research collaborations. Research Policy, 37, 900-913.

Boud, D. \& Feletti, G. (Eds.). (1991). The challenge of problem based learning. New York, NY: St. Martin's Press.

Bridges, E. \& Hallinger, P. (1992). Problem based learning for administrators. ERIC Clearinghouse on Educational Management, University of Oregon, OR.

Budimansyah, D. (2009). Inovasi Pembelajaran Project Citizen. Bandung: Program Studi PKn SPs UPI.

Center for Civic Education. (1998). We the People .. . Project Citizen: A Professional Development Manual. Calabasas, CA, USA. 
Center for Civic Education. (2020a). Project citizen research program resources. https://www.civiced.org/civitas-program-resources/instructional-materials/projectcitizen

Center for Civic Education. (2020b). Curriculum. https://www.civiced.org/projectcitizen/curriculum

Çiftçi, S. \& Sünbül A. M. (2005). Formation and development of project based learning. I. National Symposium on Contemporary Approaches in Science and Technology Education, Ankara.

Duffy, T. M. (1994). Corporate and community education: Achieving success in the information society. Bloomington, IN: Indiana University.

Erktin, E., Özkan A. \& Balcı N. (2003). Paper folding project in elementary mathematics classes. EDU7, 1 (1), 1-8.

Ersoy, A. F. (2016). Social studies teachers' and students' perception of the citizenship and democracy education course. Inonu University Journal of the Faculty of Education, 17 (3), 67-83.

Ertan, S., Yol, F. \& Savaş G. (2019). The analysis of university women's research centers web sites: logos, symbols, and activities. Journal of Higher Education (Turkey), 9 (2), $173-$ 188. doi:10.2399/yod.18.043

Evenson, D. H. \& Hmelo, C. E. (2000). Problem based learning: A research perspective on learning interactions. Mahwah, NJ: Laurence Earlbaum Associates.

Fink, I. (2004). Research space: Who needs it, who gets it, who pays for it? Planning for Higher Education, 33 (1), 5-17.

Franco, M. \& Pinho, C. (2019). A case study about cooperation between university research centres: Knowledge transfer perspective. Journal of Innovation \& Knowledge, 4 (2019), $62-69$.

Fry, S. W. \& Bentahar, A. (2013). Student attitudes towards and impressions of Project Citizen. Journal of Social Studies Education Research, 4 (1), 1-23.

Güleç-Aslan, Y. (2018). An overview of a university-based autism research and intervention center. Medeniyet Educational Research Journal, 1 (3), 1-11.

Hall, K. (2011). University research centers: heuristic categories, issues, and administrative strategies. Journal of Research Administration, 42 (2), 25-41.

Kan, Ç. (2009). Changing values and global citizenship education. Kastamonu Education Journal, 17 (3), 895-904.

Kumar, V. (2017). The role of university research centers in promoting research. Journal of the Academy of Marketing Science, 45, 453-458.

Liou, S. M. (2004). The effect of we the people ... Project Citizen on the civic skills and dispositions of Taiwanese senior high school students. Journal of Taiwan Normal University Education, 49 (1), 36-90.

Mallon, W. T. (2006). The benefits and challenges of research centers and institutes in academic medicine: findings from six universities and their medical schools. Academic Medicine, 81(6), 502-512.

Matkin, G. (2001). Organizing university economic development: Lessons from continuing education and technology transfer. In ASHE Reader in Finance in Higher Education, J. Yeager (Ed.), 275-285.

McCarthy, M., Jones, B. A. \& St. John, E. P. (2000). University-based education policy centers: Ten years later. Policy today. MO: University of Missouri System Consortium for Education Policy Analysis.

Merriam, S. B. (2001). Qualitative research and case study applications in education. San Francisco, CA: Jossey-Bass Publishers.

Miles, M. \& Huberman, A. M. (1994). Qualitative data analysis: An expanded sourcebook (2nd 
ed.). Thousand Oaks, CA: Sage.

Milter, R. G. \& Stinson, J. E. (1993). Educating leaders for the new competitive environment. In G. Gijselaers, S. Tempelaar, \& S. Keizer (Eds.), Educational innovation in economics and business administration: The case of problem-based learning. London: Kluwer Academic Publishers.

MisKelly, M. (2011). Research centers directory. Farmington Hills, MI: Gale Group, Cengage Learning Inc.

Morgan, L. A. (2016). Developing civic literacy and efficacy: insights gleaned through the implementation of Project Citizen. Inquiry in education, 8 (1), 1-18.

Ngeow, K. \& Kong, Y. (2001). Learning to learn: Preparing teachers and students for problem based learning. ERIC Digests (ERIC Identifier ED 457524).

Öksüz Gül, F. \& Alpaydın, Y. (2017). An analysis on research and application centers in Turkey. Journal of Higher Education and Science, 7 (3), 627-643.

Öztürk, T. Rapoport, A. \& Zayimoğlu Öztürk, F. (2021). Civics education in higher education: "project citizen" sample. Educational Policy Analysis and Strategic Research, 16, (2), 382-401. DOI: 10.29329/epasr.2020.345.18

Root, S. \& Northup, J. (2007). Project Citizen evaluation report. Denver, CO: RMC Research Corporation. www.civiced.org/index.php?page=project_citizen_research

Sabharwal, M. \& Hu, Q. (2013). Participation in university-based research centers: Is it helping or hurting researchers? Research Policy, 42 (6-7), 1301-1311.

Savaş, G., Ertan, S. \& Yol, F. (2018). The profile research of university women's studies centers in Turkey. Electronic Journal of Social Sciences, 17 (68), 1527-1547.

Solomon, G. (2003). Project-based learning: a primer. Technology and Learning, 23 (6).

Sonmez, D. \& Lee, H. (2003). Problem-based learning in science. ERIC Digests (ERIC Identifier ED 482724).

Stake, R. E. (2005). Qualitative case studies. In N. K. Denzin \& Y. S. Lincoln. (Ed.). The sage handbook of qualitative research (3rd edition). Thousand Oaks CA: Sage Publications.

Steffensen, M., Rogers, E. M. \& Speakman, K. (2000). Spin-offs from research centers at a research university. Journal of Business Venturing, 15 (1), 93-111.

Sulistyarini, Utami, T. \& Hasmika. (2019). Project Citizen model as character education strengthening. Journal of Education, Teaching, and Learning, 4 (1), 233-237.

Tash, W. R. (2006). Evaluating research centers and institutes for success! A manual and guide with case studies. Fredericksburg. VA: WT \& Associates.

The Council of Higher Education [CoHE]. (2020). Higher education law. https://www.mevzuat.gov.tr/MevzuatMetin/1.5.2547.pdf

Thomas, J. W., Mergendoller, J. R. \& Michaelson, A. (1999). Project-based learning: A handbook for middle and high school teachers. Novato, CA: The Buck Institute for Education.

Tolo, K. W. (1998). An assessment of we the people: Project Citizen: promoting citizenship in classrooms and communities. Austin, TX: Lyndon B. Johnson School of Public Affairs. http://www.civiced.org/index.php?page=pcassessment

Trisiana, A. (2015). Action for citizenship education of character education using Project Citizen model in senior high school in Indonesia. International Journal of Education and Psychology in the Community, 5 (1\&2), 42-53.

Vontz, T. S. \& Nixon, W. A. (1999). Issue-centered civic education in middle schools. Bloomington, IN: ERIC Clearinghouse for Social Studies/Social Science Education.

Vontz, T. S. \& Patrick, J. J. (2000). Historical and philosophical foundations of Project Citizen. In S. Mann \& J. Patrick (Eds.), Education for civic engagement in democracy: Service learning and other promising practices (pp. 93-101). Bloomington, IN: ERIC Clearinghouse for Social Studies/Social Science Education. 
Yavuz, S. (2006). Assessment of the effect of project based learning model on chemistry education students' environmental knowledge and attitudes towards environment. (Unpublished Ph.D. Thesis). Hacettepe University. Institute of Science, Ankara.

Y1lmaz, K. (2013). An investigation into elementary school students' perceptions of basic concepts about citizenship education. Hacettepe University Journal of Education, 28 (1), 453-463.

Yin, K. R. (2014). Case study research design and methods. ( $5^{\text {th }}$ Edition). Thousand Oaks, CA: Sage Publications. 